\title{
MORPHOMETRICAL ANALYSIS OF CLEANING CAPACITY USING NICKEL- TITANIUM ROTARY INSTRUMENTATION ASSOCIATED WITH IRRIGATING SOLUTIONS IN MESIO-DISTAL FLATTENED ROOT CANALS
}

\author{
ANÁLISE MORFOLÓGICA DA CAPACIDADE DE LIMPEZA PROMOVIDA PELA \\ INSTRUMENTAÇÃO ROTATÓRIA, ASSOCIADA À SOLUÇÕES IRRIGANTES, \\ COM LIMAS DE NÍQUEL-TITANNIO EM CANAIS RADICULARES COM \\ ACHATAMENTO MESIO-DISTAL
}

\author{
Melissa Andréia MARCHESAN \\ DDS, MSc, Especialista em Endodontia pela Universidade de Ribeirão Preto. \\ Marcos Porto de ARRUDA \\ Undergraduate student from Faculty of Dentistry, University of Ribeirão Preto. \\ Yara T. Correa SILVA-SOUSA \\ DDS, PhD, Faculty of Dentistry, University of Ribeirão Preto. \\ Paulo César SAQUY \\ $\mathrm{DDS}, \mathrm{PhD}$, Faculty of Dentistry, University of Ribeirão Preto. \\ Jesus Djalma PECORA \\ DDS, PhD, Restorative Dentistry Department, School of Dentistry of Ribeirão Preto, USP, Brazil. \\ Manoel D. SOUSA-NETO \\ DDS, PhD, Faculty of Dentistry, University of Ribeirão Preto.
}

\begin{abstract}
$V$ ariations in the internal anatomy of root canals may interfere with the success of root canal because tissue remnants may remain in the isthmus, re-entrances and ramifications of flattened root canals making instrumentation more difficult. Successful root canal treatment depends fundamentally on shaping, cleaning, disinfection and obturation. This study verified the quality of cleaning of ProFile .04 rotary technique associated with different irrigating solutions: $0.5 \%$ sodium hypochlorite, calcium hydroxide + Tergentol and $2 \%$ chlorhexidine in canals with mesio-distal flattening. Twelve human mandibular central incisors were randomly divided into 3 groups and instrumented up to ProFile 0.4 \#35 file after cervical preparation, and processed histologically. After optical microscopic evaluation, statistical analysis showed that the percentage of cleaning of the three irrigating solutions was statistically different. Two-by-two comparisons classified the irrigating solutions in increasing order of cleaning: calcium hydroxide + Tergentol $<$ chlorhexidine $<0.5 \%$ sodium hypochlorite.
\end{abstract}

UNITERMS: Dental pulp cavity, cleaning; Dental pulp cavity, rotary instrumentation; Flattened root canals. 


\section{INTRODUCTION}

Variations in internal anatomy can interfere with root canal therapy because root canals are not cylindrical, they are flattened. Thus, tissue remnants can persist in isthmus, re-entrances and ramifications making instrumentation more difficult 22

The success of root canal treatment depends fundamentally on cleaning, shaping, disinfecting and sealing the root canal. Cleaning occurs simultaneously with biomechanical preparation, elimination of bacteria, their sub-products, degenerated pulp tissue and contaminated dentin creating a surgical space that permits proper sealing. This process occurs by the action of the instruments on the root canal walls, the chemical properties of the irrigating solutions and irrigation-aspiration.

Many methods are used to evaluate root canal cleanliness such as scanning electron microscope ${ }^{4,11,16}$ microscope ${ }^{22}$ specimen analysis before and after instrumentation ${ }^{13}$ and recently computerized tomography ${ }^{12,21}$. BARBIZAM et al. ${ }^{2}$ observed by optic microscopic analysis of flattened root canals that instruments did not touch the polar areas during instrumentation. FARINIUK ${ }^{10}$ analyzed circular root canals and found that the capacity of efficiently cleaning the root canal is not only based on instrumentation. Irrigation is of fundamental importance ${ }^{1}$. Irrigation associated with instrumentation is necessary to remove debris for cleaning and disinfecting the root canal system.

Many auxiliary chemical solutions have been used; however, several are only registered in the literature and no longer used. Among all these solutions, sodium hypochlorite in different concentrations is most commonly used and accepted due to clarification, organic tissue dissolution, saponification, transformation of amines into chloramines, deodorizing and antibacterial effects ${ }^{18,24}$.

However, recently other solutions have also been recommended for irrigation such as chlorhexidine and HCT20 (a calcium hydroxide solution). Chlorhexidine digluconate is a broad-spectrum antibacterial agent used in Periodontics to reduce plaque formation in periodontal diseases. It also links enamel or dentine hydroxyapatite to glycoproteins anionic acid groups, and is slowly released as its concentration decreases allowing prolonged action period ${ }^{3}$. Pure or associated calcium hydroxide solutions have also been used for root canal irrigation. These solutions neutralize bacterial sub-products such as lipopolysaccharides, they are biocompatible with pulp having the same effect as saline and distilled water ${ }^{9}$ and have antiseptic properties. To improve these properties, $20 \%$ detergent was added to a calcium hydroxide solution creating HCT $20^{3}$. This association reduces surface tension and improves bacterial effect due to the increase of the diffusion rate in the bacterial cell.

Thus, this study evaluated histologically the cleaning capacity of rotary instrumentation associated with different irrigating solutions $(0.5 \%$ sodium hypochlorite, chlorhexidine and HCT20) in mesiodistally flattened root canals.

\section{MATERIAL AND METHODS}

Twelve human mandibular central incisors with a mesio-distal flattened root and radiographically confirmed single root canal were obtained from laboratory stock. The teeth were stored in $0.1 \%$ thymol and maintained at $9^{\circ} \mathrm{C}$ before use.

Conventional access was performed and a $\# 10 \mathrm{~K}$ type file was introduced into the canal until it appeared at the apical foramen. The working length was established by subtracting $0.5 \mathrm{~mm}$ from this measurement. The teeth were randomly divided into 3 groups of 4 teeth each. All teeth were prepared according to Guerisoli et al. ${ }^{14}$ using rotary instrumentation and ProFile .04 Ni-Ti files (DentsplyMaillefer, Ballaigues, Switzerland) as follows: after initial enlargement with a stainless steel \#15 file, an ascending sequential ProFile instrumentation (\# 15 to \#40) was performed to the working length.

In group 1, $2 \mathrm{ml}$ of $0.5 \%$ sodium hypochlorite was used, between files, as an irrigating solution; in group 2, $2 \mathrm{ml}$ of HCT20 was used between files and in group $3,2 \mathrm{ml}$ of chlorhexidine was used between files. Ten $\mathrm{ml}$ of distilled and deionized water was used for final irrigation in all groups to remove solution residue.

The apical third of each root was sectioned and removed for histological processing. The specimens were immersed in $10 \%$ buffered formalin and stored for $12 \mathrm{~h}$ in the same solution until histological processing. All specimens were then washed, decalcified in $10 \%$ glycoacetic acid and embedded in paraffin. Serial transverse cross-sections $(5 \mathrm{~mm})$ were stained with hematoxylin and eosin. The cross-sections were examined with an optic microscope (40x) coupled to a computer where the images were recorded. A grid was placed over these images to evaluate the total canal area and tile area with debris. The percentage of debris in the root canal after chemomechanical preparation was calculated and the nonparametric Kruskal-Wallis test was used for statistical analysis. 


\section{RESULTS}

The results of percentage of cleaning of the root canal are shown in Table 1.

Due to the non-normality of the sample, the nonparametric Kruskal-Wallis test was applied and the irrigating solutions were placed in ascending order of cleaning efficiency. Sodium hypochlorite $(0.5 \%)$ (Figure 1) was the most effective and HCT20 (Figure 2 ) was the least effective for cleaning the root canals. Chlorhexidine (Figure 3) showed an intermediate position.

\section{DISCUSSION}

Biomechanical preparation of the root canal is a basic requirement of root canal preparation. Its aim consists of cleaning the canal and its ramifications, removing most of the debris to create ideal conditions, which lead to healing and tissue regeneration.

Researchers have shown that chemical-mechanical preparation leave organic and inorganic debris in the root canals ${ }^{5-8,20}$.

BARBIZAM et al. ${ }^{2}$ demonstrated that rotary instrumentation with $\mathrm{Ni}$ - Ti files have a delimitated action area leaving polar areas of flattened root canals un-instrumented where the dentine canaliculli disposal favors microorganism maintenance.

Thus the use of an irrigating solution with specific chemical properties, among this organic tissue dissolution, and the association between instrumentation techniques to fulfill the lacune left by rotary instrumentation in this group of teeth is necessary.

This study evaluated the effect of different irrigating solutions associated to rotary instrumentation to clean the root canal. Due to the nonnormality of the sample the Kruskal-Wallis test was performed between the groups. Sodium hypochlorite $(0.5 \%)$ was the most effective and HCT20 was the least effective on cleaning the root canals. Chlorhexidine showed an intermediate position.

The best results were found for $0.5 \%$ sodium hypochlorite due to its dissolution activity as shown by: MOORER \& WESSELINK ${ }^{19}$, SPANÓ et al. ${ }^{24}$. Which established important factors that interfere in this solution: a) quantity of solution related to organic tissue mass; b) contact surface; c) action time; d) solution volume; e) mechanical agitation f) solution

TABLE 1. Percentage of transversal area of the root canal containing debris

\begin{tabular}{llll}
\hline Third & & Irrigating Solutions & \\
\hline & NaClO & HCT20 & Clorexidina \\
\hline & 0,00 & 36,15 & 32,81 \\
Apical & 0,00 & 27,58 & 8,40 \\
& 3,57 & 61,81 & 13,41 \\
& 12,40 & 34,78 & 22,92 \\
\hline
\end{tabular}

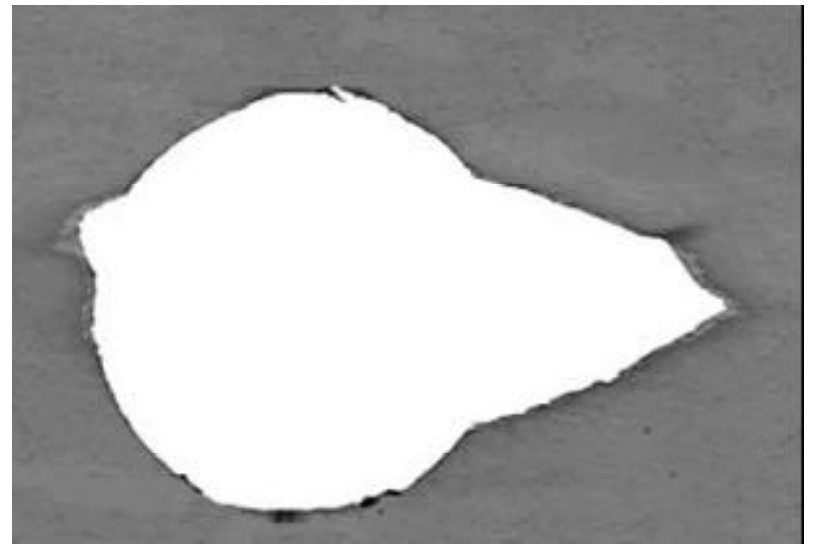

FIGURE 1- Slide showing a root canal from group 1, with the presence of pre-dentin

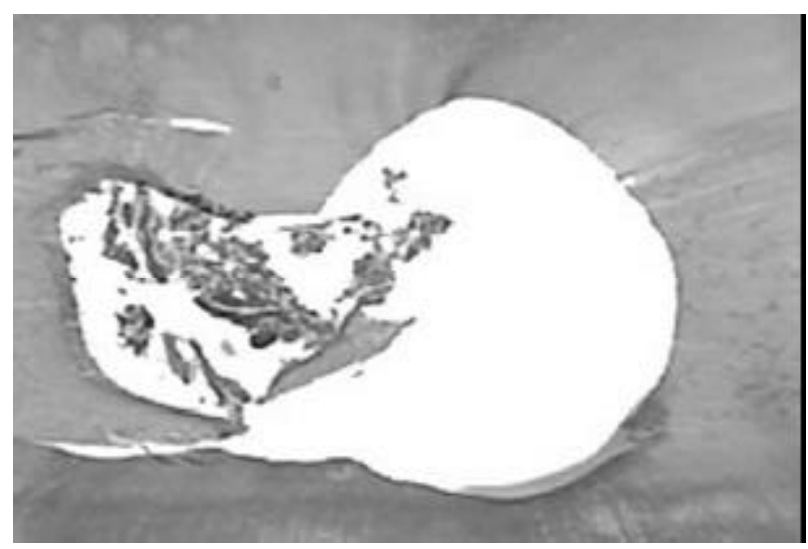

FIGURE 2- Slide showing a root canal from group 2, with the presence of débris 


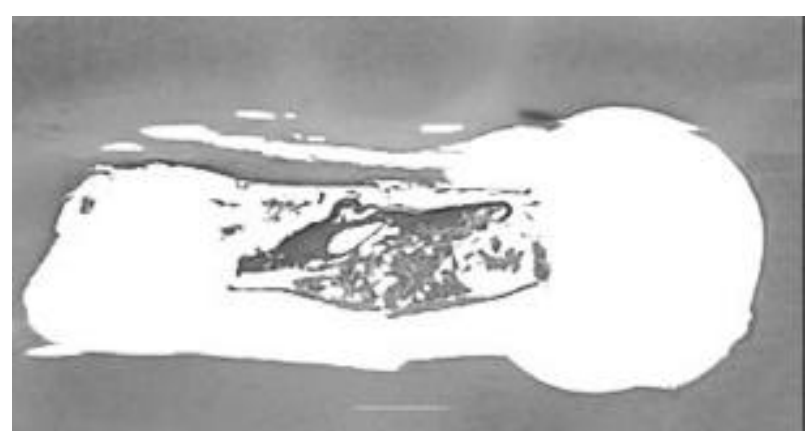

FIGURE 3- Slide showing a root canal from group 3, with the presence of debris

temperature; and g) solution concentration. Thus, the higher these values the better the dissolution capacity of sodium hypochlorite necrotic or not organic tissue.

Sodium hypochlorite dissolution capacity liquefies the pulp and eases its removal from root canal interior. SPANÓ et al. ${ }^{24}$ showed that the higher the concentration of sodium hypochlorite the faster the dissolution of the pulp tissue. Evidencing that in flattened root canals the use of an irrigating solution is necessary to dissolve pulp in the areas where the instrument does not touch.

The HCT20 solution showed the lower percentage of cleaning values. HASSELGREN et al. ${ }^{15}$ demonstrated that calcium hydroxide dissolves organic tissue and that the effect of sodium hypochlorite is increased by previous calcium hydroxide treatment. In our study, even with the adding of detergent, which lowers superficial tension, there was no increase in the cleaning effect.

BARBOSA ${ }^{3}$ showed that chlorhexidine does not present dissolution capacity however presents excellent antibacterial effect ${ }^{17,23}$.

Based on the results obtained in this study we conclude that the use of an efficient irrigating solution during flattened root canal chemical-mechanical preparation is necessary to improve cleaning.

\section{CONCLUSIONS}

1) None of the tested solutions associated to rotary instrumentation lead to complete root canal cleaning;

2) $0.5 \%$ sodium hypochlorite presented the higher cleaning capacity followed by $2 \%$ chlorhexidine and HCT20.

\section{RESUMO}

As variações da anatomia interna de cada canal radicular podem interferir no sucesso da terapêutica endodôntica devido ao fato de que em canais radiculares achatados, pode persistir remanescentes teciduais em istmos, reentrâncias e ramificações dificultando a execução das técnicas de instrumentação. O sucesso do tratamento dos canais radiculares depende fundamentalmente do preparo da forma, limpeza, desinfecção e obturação. Poucos trabalhos avaliaram a limpeza dos canais radiculares após a instrumentação rotatória. O presente trabalho verificou a qualidade de limpeza dos canais radiculares, por meio da microscopia óptica, promovida pela técnica de instrumentação rotatória associada ao hipoclorito de sódio $0,5 \%$, HCT20 e clorexidina, em canais achatados no sentido mésiodistal. Doze incisivos centrais inferiores humanos foram divididos aleatoriamente em três grupos para que fossem instrumentados com instrumetação rotatória (ProFile .04). A análise estatística evidenciou que os valores da porcentagem de limpeza para as diferentes soluções irrigantes foram estatisticamente diferentes entre si. Comparações duas a duas permitiram dispor as soluções irrigantes em ordem crescente de efetividade na limpeza, sendo: hipoclorito de sódio a $0,5 \%$ > clorexidina > HCT 20 .

UNITERMOS: Cavidade da polpa dentária, limpeza; Cavidade da polpa dentária, instrumentação rotatória; Canais radiculares achatados.

\section{REFERENCES}

1- Baratto-Filho F. Estudo in vitro da capacidade de limpeza do canal radicular com achatamento através de instrumentação rotatória e irrigação com hipoclorito de sódio em três diferentes concentrações - análise histológica. Ribeirão Preto; 2002. [Dissertação de Mestrado - Curso de Odontologia da Universidade de Ribeirão Preto].

2- Barbizam JVB, Fariniuk LF, Marchesan MA, Pecora JD, SousaNeto MD. Effectiveness of Manual and Rotary Instrumentation Techniques for Cleaning Flattened Root Canals. J Endod 2001; 28: 365-66.

3- Barbosa SV. Terapêutica Endodôntica. São Paulo: Santos; 1999.

4- Bechelli C, Orlandini SZ, Colafranceschi M. Scanning electron microscope study on the efficacy of root canal wall debridement of hand versus Lightspeed instrumentation. Int Endod J 1999; 32: 484-93. 
5- Costa WF, Antoniazzi SH, Campos MNM, Pécora JD, Robazza CRC. Avaliação comparativa, sob microscopia ótica, da capacidade de limpeza da irrigação manual convencional versus ultra-sônica dos canais radiculares. Rev Paul Odont 1986; 8: 50-60.

6- Crabb HSM. The cleaning of root canals. Int Endod J 1982; 15: 62-6.

7- Cunninghan WT, Martin H, Forrest WR. Evaluation of root canal debridement by the endosonic ultrasonic synergistic system. Oral Surg 1982; 53: 401-4.

8- Esberard RM, Leonardo MR, Utrilla LS, Ramalho LTO, Bonetti Filho I. Avaliação histológica comparativa da eficiência da instrumentação manual e ultrassônica em canais atresiados e amplos. Odont Clin 1987; 1(3): 15-8.

9- Estrela C, Bammann LL, Pimenta FC, Pécora JD. Control of microorganisms in vitro by hidroxide pastes. Int Endod J 2001; 34: $341-5$

10- Fariniuk, L. Análise histológica da capacidade de limpeza de instrumentos endodônticos mecanizados acionados pelo Sistema Endoflash. Ribeirão Preto; 2002. [Dissertação de Mestrado - Curso de Odontologia da Universidade de Ribeirão Preto].

11- Gambarini G. Shaping and cleaning the root canal system: a scanning electron microscopic evaluation of a new instrumentation and irrigation technique. J Endod 2000; 25: 800-3.

12- Gambil JM, Alder M, Del Rio CE. Comparison of Ni-Ti and Stainless steel hand files using computed tomography. J Endod 1996; 22: 369-75.

13- Glosson CR, Haller RH, Dove SB, Del Rio CE. A comparison of root canal preparations using $\mathrm{Ni}-\mathrm{Ti}$ hand, $\mathrm{Ni}-\mathrm{Ti}$ engine-driven, and K-flex endodontic instruments. J Endod 1995; 21:146-151.

14- Guerisoli DMZ. Mecanismo de ação dos instrumentos rotatórios. Ribeirão Preto; 1999. [Monografia de Especialização Curso de Odontologia da Universidade de Ribeirão Preto.

15- Hasselgren ML, Golsson B, Cvec M. Effects of calcium hydroxide and sodium-hypochlorite on the dissolution of necrotic porcine muscle-tissue. J Endod 1988; 14: 125-27.

16- Hülsmann M, Rümmelin C, Schäfers F. Root canal cleanliness after preparation with different endodontic handpieces and hand instruments: A comparative SEM investigation. J Endod 1997; 23: $301-6$

17- Jeansonne MJ; White RR. A comparison of $2.0 \%$ chlorhexidine gluconate and $5.25 \%$ sodium hypochlorite as antimicrobial endodontic irrigants. J Endod 1994; 20: 276-8.

18- Marchesan MA, Souza RA, Guerisoli DMZ, Silva RS. Análise de algumas propriedades físico-químicas das águas sanitárias encontradas no mercado brasileiro. RBO 1998; 55: 301-3.

19- Moorer WR; Wesselink PR. Factors promoting the tissue dissolving capability of sodium hypochlorite. Int Endod J 1982; 15: 187-196.
20- Moodnik RM, Dorn SO, Feldman MJ, Levey M, Borden BO. Efficacy of biomechanical instrumentation: A scanning electron microscopic study. J Endod 1976; 2: 261-6.

21- Peters OA; Barbakow F. Effects of irrigation on debris and smear layer on canal walls prepared by two rotatory techniques: A scanning electron microscopic study. J Endod 2001; 26: 6-10.

22- Siqueira JF, Araújo MC, Garcia PF, Fraga RC, Dantas CJ. Histological evaluation of the effectiveness of five instrumentation techniques for cleaning the apical third of root canals. J Endod 1997; 23: 499-502.

23- Siqueira JF, Batista MMD, Fraga RC, Uzeda M. Antibacterial effects of endodontic irrigants on black-pigmented gram-negative anaerobes and facultative bacteria. J Endod 1998; 23: 414-16.

24- Spanó JCE, Barbin ELB, Santos TC, Guimaraes LF, Pecora JD. Solvent action of sodium hypochlorite on bovine pulp and physico-chemical properties of resulting liquid. Braz Dent J 2001; 12: 154- 57, 2001.

Corresponding author: Manoel Sousa-Neto

Rua Celia de Oliveira Meirales, 350

Jd Canada, 14024-070

Ribeirão Preto, SP, Brasil.

e-mail: sousanet@unaerp.br 